\title{
EFEK APOMORFIN SUBLINGUAL PADA EREKSI PENIS
}

\author{
Kaleb D. S. Salossa \\ Sonny J. R. Kalangi \\ Ghazaly Adam
}

\author{
Bagian Anatomi-Histologi Fakultas Kedokteran Universitas Sam Ratulangi Manado \\ Email: sonnykalangi@yahoo.com
}

\begin{abstract}
Erectile dysfunction is the disability of a male to maintain consistant or repeated penile erections sufficiently for successful sexual intercourse. Many efforts have been done to handle this condition, so far. The psychosocial therapy and several medications inter alia: testosterone, yohimbine, trazadone, direct intracavernosus injection of alprostadil, penile implantation, and sildenafil citrate, are not always suitable for the patients' needs, especiallly those who suffer from cardiovascular diseases. Therefore, a new erectogenic agent has been introduced, the sublingual apomorphine. This apomorphine has a dopamine-like molecule that acts on the dopamine receptors in the paraventricular nucleus (PVN) of the central nervous system to increase the penile erection due to sexual stimulation (erotic imagination, audiovisual, or tactile). The sublingual apomorphine has been proved effective in overcoming the erectile dysfunction, especially the mild and moderate forms.
\end{abstract}

Keywords: penile erection, sublingual apomorphin.

\begin{abstract}
Abstrak: Telah banyak upaya dilakukan untuk mengatasi disfungsi ereksi yang merupakan ketidakmampuan seorang laki-laki secara konsisten atau berulang untuk mencapai dan mempertahankan ereksi penis yang cukup untuk melakukan hubungan seksual. Terapi psikososial dan pengobatan yang pernah diajukan seperti pemberian hormon testosteron, yohimbin, trazadon, injeksi langsung alprostadil intrakavernosa, implantasi penis serta sildenafil sitrat tidaklah selalu sesuai dengan kebutuhan penderita, khususnya penderita disfungsi ereksi dengan penyakit kardiovaskuler. Para ahli berusaha melakukan terobosan baru salah satunya adalah apomorfin sublingual yang merupakan agen erektogenik baru. Apomorfin adalah suatu molekul mirip dopamin yang bekerja pada reseptor dopamin pada paraventricular nucleus (PVN) di sistem saraf pusat untuk meningkatkan rangsangan erektil saat stimulasi seksual (imaginasi erotik, audiovisual dan perabaan) terjadi. Apomorfin sublingual terbukti efektif untuk mengatasi disfungsi ereksi, terutama disfungsi ereksi ringan dan sedang.
\end{abstract}

Kata kunci: ereksi penis, apomorfin sublingual.

Ereksi penis mempunyai peranan yang sangat penting dalam perilaku seksual pria dan merupakan suatu kebutuhan utama bagi kehidupan rumah tangga suami istri. Sebagian besar laki-laki dalam masyarakat pada umumnya menganggap kepuasan seksual sebagai suatu ukuran kepuasan hidup seseorang. Laki-laki yang tidak puas secara seksual sering malu, bingung, atau depresi. Hal tersebut dianggap sebagai refleksi buruknya kehidupan sebagai laki-laki. ${ }^{1,2}$

Akhir-akhir ini telah banyak dilakukan upaya untuk mengatasi gangguan ereksi. Seorang laki-laki dikatakan mengalami gangguan ereksi bila tidak mempunyai kemampuan yang bersifat menetap atau berulang dengan masa paling sedikit tiga bulan, untuk mencapai atau mempertahankan ereksi yang cukup agar dapat melakukan senggama yang memuaskan. 
Gangguan yang disebut disfungsi ereksi ini, merupakan masalah kaum lelaki yang sudah ada sejak ribuan tahun lalu dan hingga sekarang secara epidemiologi cukup tinggi. ${ }^{1,2}$

Pilihan terapi gangguan fungsi ereksi yang tersedia saat ini dibagi menjadi tiga lini. Terapi lini pertama meliputi terapi seks atau psikososial dan agen erektogenik oral. Lini kedua meliputi vakum konstriksi, injeksi intra-kavernosa dan pengobatan intra-uretra, sedangkan lini ketiga melalui tindakan operasi atau protesa. Untuk pilihan terapi tersebut di atas, pengobatan yang pernah diajukan yaitu pemberian hormon testosteron, yohimbin, sildenafil sitrat, trazadon, injeksi langsung alprostadil intrakavernosa, penggunaan tabung vakum, dan implantasi penis.

Penggunaan obat-obat tersebut di atas, seperti yohimbin, dilaporkan sangat efektif pada gangguan disfungsi ereksi yang psikogenik, sedangkan trazadon dapat memberikan hasil yang lebih baik bila diberikan bersama dengan yohimbin. Oleh karena itu, adanya terobosan baru dengan pemberian apomorfin sub-lingual yang merupakan agen oral erektogenik baru pada penelitian memberikan efek yang baik dalam meningkatkan ereksi penis. Apomorfin ialah suatu molekul dopamin yang bekerja pada reseptor dopamin di sistem saraf pusat untuk meningkatkan rangsangan ereksi. Pemberian apomorfin secara sublingual menyebabkan kerja obat yang cepat. ${ }^{3}$

Keadaan relaksasi atau kontraksi otot polos arteri dan trabekula korpus kavernosum menentukan penis dalam keadaan ereksi atau lemas. Otot polos yang menyusun korpus kavernosum ini dipersarafi oleh nervus kavernosus. Pada saat terjadi rangsangan seksual, impuls saraf akan menyebabkan terjadinya relaksasi otot polos, sehingga darah mengalir masuk ke dalam korpus kavernosum dan terjadilah ereksi penis. ${ }^{4,5}$

\section{PUSAT KONTROL EREKSI PENIS}

Fungsi ereksi normal merupakan respon dibawah kontrol sistem saraf pusat dan melibatkan otak, medula spinalis, dan saraf perifer. Terdapat bagian-bagian di otak yang dapat dianggap sebagai pusat kontrol di supra-spinal untuk pengendalian ereksi penis, termasuk struktur di korteks, talamus, sistem limbik, serta beberapa nukleus di medula spinalis, pons dan hipotalamus. $^{12,13}$

Hipotalamus memainkan peran penting dalam mengatur ereksi penis, terutama melalui dua nukleus yaitu medial preoptic area (MPOA) dan paraventricular nucleus (PVN). MPOA sangat terkait dengan regio di otak sehingga dapat mengintegrasikan berbagai informasi dari pusat dan perifer serta memiliki peran yang sangat luas dalam mengendalikan perilaku seksual. Meskipun MPOA tidak memiliki hubungan dengan medula spinalis tetapi neuronneuronnya diproyeksikan pada PVN dan neuron-neuron parvoseluler PVN secara langsung diproyeksikan ke atas medula spinalis. Aktivasi listrik PVN juga memicu terjadinya ereksi penis. ${ }^{13,14}$

Jalur neural yang turun dari PVN ke medula spinalis mengandung berbagai neurotransmiter, termasuk oksitosin, vasopresin, enkepalin, dan dopamin. Khususnya oksitosin, merupakan perantara penting dalam pusat kontrol ereksi penis. Mikroinjeksi intratekal sejumlah oksitosin pada tingkat lumbosakral medula spinalis menunjukkan induksi terhadap ereksi penis dimana terjadi peningkatan tekanan intrakavernosa. Stimulasi listrik pada nervus dorsalis penis akan merangsang sel-sel oksitosin di dalam PVN dan menunjukkan preferensial inervasi oksito-sinergik oleh afferent sensory input. Dengan demikian, aktivitas neuron oksito-sinergik memproyeksikan dari PVN menuju spinal parasympatic centre untuk memengaruhi keseimbangan ereksi. ${ }^{15-18}$

Jalur parasimpatis yang keluar dari pusat-pusat di medula spinalis (segmen $\mathrm{S}_{2}$ $\mathrm{S}_{4}$ ) juga menyediakan masukan rangsangan utama ke penis dan bertanggung jawab untuk vasodilatasi pembuluh-pembuluh darah yang mengarah ke penis. Perjalanan eferen parasimpatis ke penis melalui serat saraf preganglion di dalam saraf pelvis dan 
menuju pleksus pelvis. Jalur simpatis yang menghambat ereksi dikeluarkan dari medula spinalis torakal bawah dan lumbal atas. Perjalanan serat simpatis melalui rantai simpatis kemudian saraf pudendus atau melalui saraf-saraf splanikus lumbar, pleksus mesenterika inferior kemudian saraf hipogastrik dan pleksus pelvis. Sel ganglion parasimpatis dan simpatis dari pleksus pelvis mengirim akson ke penis melalui saraf-saraf kavernosus. Jalur sensoris yang penting dalam refleksogenik ereksi penis mengirimkan informasi ke sistem saraf pusat melalui saraf-saraf dorsalis penis dan saraf-saraf pudendus. ${ }^{18,19}$

\section{ASPEK MOLEKULER EREKSI PENIS}

Nitrik oksida (NO) dari endotel yang dilepaskan pada saat transmisi saraf nonadrenergik non-kolinergik merupakan neurotransmiter terpenting yang memerantarai ereksi penis serta merupakan suatu perantara antar sel yang menyebabkan vasodilatasi dengan merelaksasikan otot polos vaskular. NO juga merupakan endothelium derived factor (EDRF), yang dibentuk dari arginin dan dikatalisis oleh NO sintase. Terdapat bukti bahwa ereksi penis dihasilkan oleh pelepasan NO yang mengakibatkan vasodilatasi dan pengisian korpus kavernosum. Penyuntikan inhibitor sintase dapat mencegah ereksi yang secara normal timbul setelah rangsangan pada saraf-saraf panggul hewan percobaan. Dengan demikian NO merupakan mediator ereksi yang penting. Adenosin monofosfat siklik (cyclic adenosine monophosphate) dan guanosin monofosfat siklik (cyclic guanosine monophosphate, cGMP,) ialah perantara kedua intrasel yang memerantarai relaksasi otot polos. ${ }^{18,19}$

Asetilkolin juga merupakan neurotransmiter yang berpotensi merelaksasikan otot polos trabekula. Sistem saraf parasimpatis menekan adrenergik dan meningkatkan aksi NO pada jaringan korpus kavernosum penis. Reseptor asetilkolin muskarinik subtipe muskarinik-1 (m1AChR) merupakan reseptor yang terli-bat pada saraf kolinergik bisa juga mengaktifkan neurotransmiter non-adrenergik nonkolinergik. Selanjutnya, stimulasi reseptor asetilkolin menghasilkan NO melalui NO sintase (enzim yang mengatalisis pembentukan NO dari arginin) pada endotel. Di dalam otot polos, NO mengaktifkan guanilil siklase yang mengubah guanosine triphosphate (GTP) menjadi cGMP. cGMP ini mengaktifkan protein kinase spesifik yang memfosforilasi protein tertentu dan menyebabkan terbukanya saluran kalium dan hiperpolarisasi membran sel otot, pengambilan kalsium oleh retikulum endoplasmik, dan penghambatan saluran masuk kalsium. Akibatnya, konsentrasi kalsium sitosol menurun dan terjadilah relaksasi otot polos. Pada waktu penis kem-bali ke keadaan lemas, cGMP didegradasi menjadi GMP oleh fosfodiesterase tipe-5 (PDE5). Fosfodiesterase tipe lain juga terdapat didalam korpus kavernosum, tetapi tidak mempunyai peran penting dalam ereksi. ${ }^{18,19}$

\section{APOMORFIN SUBLINGUAL}

Apomorfin ialah agonis dopamin dengan afinitas bagi reseptor dopamin-1 dan reseptor dopamin-2 di hipotalamus yang terkait antara lain pada regulasi fungsi ereksi. Sejak apomorfin pertama kali disintesis melalui perlakuan asam morfin pada tahun 1869, apomorfin telah digunakan secara luas dan sukses dalam terapi berbagai variasi kondisi klinis, termasuk penyakit Parkinson. Percobaan klinik terhadap sekitar 5000 pasien yang dilaporkan menunjukkan efek terapi yang aman. ${ }^{20}$

Apomorfin berdasarkan sistem penanamaan IUPAC (International Union of Pure and Applied Chemistry) ialah apomorfin hidroklorida, 4H-di benzo (de-9) quinoline-10,11-diol, 5, 6, 6a, 7-tetrahidro6-6 metil-hemihidrat-[R]- $\left(\mathrm{C}_{17} \mathrm{H}_{18}\right.$ (CNo.2. $1 / 2 \mathrm{H}_{2} \mathrm{O}$ ). Berat molekul apomorfin 312,8. Apomorfin dihasilkan melalui dehidrasi morfin diikuti oleh penyusunan kembali kerangka dimana empat dari lima sumbu simetris pada morfin dieliminasi. Apomorfin juga memiliki kesamaan dengan morfin tetapi tidak memiliki sifat adiktif dari morfin atau analgetik dari narkotik. 
Apomorfin bebas larut dalam etanol atau aseton, sedikit larut dalam air, dan lebih khusus dapat larut dalam kloroform. ${ }^{20}$

Sifat dopaminergik dari apomorfin yang ditunjukkan merupakan campuran reseptor agonis dopamin $\mathrm{D}_{1}$ dan $\mathrm{D}_{2}$ ' dengan potensial aksi yang lebih besar pada $\mathrm{D}_{2}{ }^{21}$

\section{FARMAKOKINETIK}

Onset yang cepat dari pengaruh apomorfin sublingual merupakan refleks kecepatan absorbsi apomorfin melalui rongga sublingual. Apomorfin tampaknya tidak efektif bila ditelan atau diminum; dan hanya $1-2 \%$ pengaruh dapat dilihat setelah pemberian intravena dan subkutan. Karena formulasi sublingual, apomorfin tidak mungkin untuk berinteraksi dengan makanan sehingga makanan dan alkohol dalam saluran perncernaan tidak dapat menghambat efek kerja apomorfin. Apomorfin lebih cepat diabsorbsi melalui rute sublingual, dengan waktu untuk mencapai konsentrasi plasma maksimal 40-60 menit. Konsentrasi plasma maksimal (Cmax) dan area under plasma concentration time curve (AUC) mengalami peningkatan secara proporsional terhadap dosis sublingual. ${ }^{22,23}$ Bioavilibilitas apomorfin sublingual yang dicapai melalui injeksi subkutan ialah 16-18\%.

Pada percobaan secara in vitro, protein yang terikat pada plasma (plasma binding protein) diperkirakan sekitar $90 \%$, terutama terhadap albumin; dan konsentrasi yang bebas atau tidak terikat pada protein plasma sekitar 1-100ng/ml. Volume distribusi tersebut diperkirakan cukup besar. Apomorfin sublingual sangat mudah larut dalam lemak (lipid soluble) sehingga dapat melewati sawar darah otak (blood-brain barrier) untuk mencapai konsentrasi enam kali lebih tinggi daripada konsentrasi yang ada di plasma. ${ }^{23,24}$

Jalur metabolisme utama untuk untuk apormofin sublingual adalah sulfasi, glukoronidasi dan $\mathrm{N}$-demetilasi yang akan menghasilkan nor-apomorfin. Selain itu, terdapat jalur metabolisme lain, yaitu O-metilasi yang akan menghasilkan metabolit- metabolit kecil seperti isoapokodein dan apokodein. Sulfasi, glukoronidasi, Ndemetilasi dan O-metilasi ini merupakan reaksi konjugasi yang biasanya juga merupakan reaksi detoksikasi dan melibatkan gugus fungsional polar seperti karboksil, hidroksil dan amino. Selain itu, studi human hepatic microsomal secara invitro menunjukkan bahwa apomorfin menghambat CYP1A2, CYP2D6 dan CYP3A4. Ketiga bahan ini merupakan enzim-enzim yang dihasilkan oleh sitokrom P450 yang terdapat dalam sel-sel hati. Sitokrom P450 ini berperan dalam sintesis maupun metabolisme molekul-molekul kimia dalam sel dan sebagian proses metabolisme obat ini terjadi dalam retikulum endoplasma sel hati. ${ }^{23-25}$

Konsentrasi plasma yang lebih rendah dari apomorfin setelah pemberian dosis sublingual disertai dengan waktu paruh yang singkat, membuatnya secara bermakna menghindari hambatan sitokrom P450 yang memerantarai metabolisme obat-obat lain; atau karena kerja obat yang cepat melalui pemberian sublingual, membuatnya tidak perlu melalui metabolisme di hati sehingga menghindari interaksi obat dengan sitokrom P450. ${ }^{23-25}$

Setelah pemberian subkutan, maka klirens apomorfin plasma sangat cepat, dengan total klirens plasma diperkirakan mencapai 3-4 L/h/kg. Waktu paruh yang tampak jelas pada fase akhir dari apomorfin sekitar tiga jam setelah pemberian subkutan atau sublingual. Setelah pemberian apomorfin sublingual, radioaktivitas telah dieliminasi baik dari air seni (93\%) dan feses (16\%), dan kurang dari 2\% ditemukan dalam air seni sebagai apomorfin yang tidak terkonjugasi. Di dalam air seni tersebut, 55\% radioaktivitas telah ditemukan kembali dalam waktu 12 jam, dan lebih dari $90 \%$ dalam waktu 48 jam. Selain itu, diperkirakan terdapat sekitar 55\% dari dosis yang dieksresikan dalam air seni sebagai apomorfin sulfat, $12 \%$ sebagai apomorfin glukoronat, dan $18 \%$ yang bebas (tidak dieliminasi). Sampel-sampel urin yang dikumpulkan dari subjek penelitian yang diberikan apomorfin sublingual ter- 
sebut dievaluasi sesuai standar tes obat dan tidak ditemukan adanya reaksi silang, terutama dengan morfin atau kodein. ${ }^{24,26,27}$

\section{INTERAKSI OBAT}

Penelitian human hepatik microsomal secara in vitro menunjukan bahwa apomorfin menghambat aktifitas dari CYP1A2, CYP2D6, dan CYP3A. Hambatan hanya dapat terjadi pada konsentrasi terapeutik yang lebih tinggi dari apomorfin sublingual dan waktu paruh yang ditunjukkan singkat. Apomorfin sublingual tidak dapat berinteraksi dengan obat lainnya melalui metabolisme yang diperantarai sitokrom P450. Selain konjugasi dan demetilasi-N apomorfin juga mengalami metilasi-O oleh cathecol-O-methyltransferase (COMT). Telah dianjurkan bahwa apomorfin digunakan dengan hati-hati atau dosis akan dikurangi bila digunakan bersamaan dengan inhibitor COMT seperti entakapon dan tolkapon. ${ }^{27,28}$

Dalam studi interaksi alkohol, subjek yang sehat diberi minuman etanol 30 menit sebelum pemberian apomorfin sublingual pada dosis yang lebih tinggi daripada dosis yang dianjurkan. Pemberian alkohol dosis rendah $(0,3 \mathrm{~g} / \mathrm{kg})$ dengan apomorfin sublingual dosis 5 atau $6 \mathrm{mg}$ tidak berpengaruh pada masing-masing bioavilibilitasnya walaupun dengan dosis alkohol yang lebih tinggi $(0,6 \mathrm{~g} / \mathrm{kg})$. Hal ini berarti $\mathrm{C}_{\max }$ dan AUC dari apomorfin sublingual dan etanol telah direduksi. Selain itu, juga ditemukan peningkatan prevalensi dari nausea, pusing, muka tampak pucat, dan hipotensi ketika etanol dan apomorfin sublingual digunakan dalam kombinasi. ${ }^{25,27,28}$

Dengan terdapatnya kecenderungan menyebabkan arterial hypotension, apomorfin sublingual berpotensi untuk berinteraksi secara farmakodinamik dengan antihipertensi atau nitrat. Dalam studi cross over secara random yang melibatkan 162 orang dengan penggunaan antihipertensi jangka panjang atau nitrat jangka pendek dan jangka panjang, pemberian yang lebih tinggi dari dosis yang dianjurkan untuk apomorfin sublingual (5mg) dapat menurunkan tekanan darah sistolik sebesar 10
mmHg dan 6 mmHg bersamaan dengan pemberian $\alpha 1$-blocker dan calcium channel blocker. $^{29-31}$

\section{INDIKASI, DOSIS, DAN PEMBERIAN}

Apomorfin sublingual diindikasikan untuk pengobatan disfungsi ereksi dan tersedia dalam dua dosis, yaitu $2 \mathrm{mg}$ dan 3 mg. Onset yang dicapai dengan pemberian apomorfin sublingual 2 dan $3 \mathrm{mg}$ ialah sekitar 18-19 menit dengan variasi individual. ${ }^{10}$ Tablet sangat baik larut dalam kondisi basah sehingga sebaiknya pasien minum sedikit air sebelum diberikan tablet apomorfin sublingual.

Pasien harus menghindari kelebihan konsumsi alkohol sebelum pemberian apomorfin sublingual dan aktivitas seperti mengemudi atau mengoperasikan mesin minimal dua jam hingga gejala benar-benar sudah pulih. ${ }^{30,31}$ Jika pasien mengalami gejala prodormal seperti nausea, muntah, muka tampak pucat, berkeringat, dan pusing maka pasien tersebut harus berbaring dengan kaki terangkat ke atas sampai gejala-gejala pulih.

Dosis yang direkomendasikan dimulai dengan dosis $2 \mathrm{mg}$ untuk semua pasien. Jika diperlukan, dosis dapat ditingkatkan hingga $3 \mathrm{mg}$ dan rata-rata keberhasilan pengobatan meningkat dengan dosis yang diulang. Pasien disarankan untuk menjalani pengobatan suatu saat dengan apomorfin sublingual $2 \mathrm{mg}$ dan diikuti sedikitnya empat kali dengan tablet $3 \mathrm{mg}$. Penyesuaian dosis tidak diperlukan untuk orang lanjut usia. Pasien dengan gangguan organ hati yang nyata hanya dapat diberikan apomorfin sublingual bila manfaatnya melebihi risiko. Jika apomorfin sublingual digunakan pada pasien dengan gangguan fungsi hati maka harus dimulai pada $2 \mathrm{mg}$ dan dosis ditingkatkan dengan hati-hati saat diperlukan. Pada pasien dengan gangguan ginjal berat, maka dosis harus dibatasi sampai 2 mg. ${ }^{32-34}$

\section{KONTRA INDIKASI DAN EFEK SAM- PING}

Pada pasien dengan riwayat penyakit 
jantung yang telah ada sebelumnya dapat terjadi peningkatan risiko kardiovaskuler selama melakukan aktivitas seksual dengan atau tanpa agen yang berhubungan dengan farmakologi. Dengan demikian, status kardiovaskular harus dinilai sebelum melakukan perawatan disfungsi ereksi pada pasien-pasien dengan risiko tinggi. Produsen atau pabrik pembuat obat merekomendasikan agar apomorfin sublingual dikontraindikasikan pada pasien-pasien dengan severe unstable angina, myocardial infarction, severe heart failure, atau hipotensi dan keadaan-keadaan lain dimana aktivitas seksual terganggu atau adanya kelainan yang mempengaruhinya. ${ }^{35,36}$

Karena kemungkinan penurunan tekanan darah akibat pemberian apomorfin sublingual, maka obat ini harus digunakan dengan hati-hati pada pasien yang sedang menjalani pengobatan dengan antihipertensi, nitrat atau alkohol, pada pasienpasien dengan hipertensi tidak terkontrol, hipotensi atau riwayat hipotensi postural dan pada pasien-pasien dengan deformitas anatomi penis (misalnya angulasi) atau pada pasien yang rentan terhadap priapismus (misalnya multipel mieloma). Apomorfin sublingual juga tidak ditujukan bagi perempuan sebagai agen farmakologi untuk meningkatkan aktivitas reproduksi. ${ }^{34-36}$

Pada pasien-pasien yang menggunakan nitrat jangka panjang, apomorfin mengurangi tekanan darah sistolik dan diastolik hingga $10 \mathrm{mmHg}$ pada posisi berdiri, namun tidak dengan posisi terlentang. Perubahan dalam tekanan darah dan frekuensi jantung secara klinik cukup bermakna pada pasien-pasien yang menggunakan ACE inhibitors, beta-bloker, diuretik, dan nitrat jangka pendek. Sindrom vasovagal terjadi pada $16 \%$ dari pasien, 5\% memiliki hipotensi simptomatik dan satu pasien dengan penggunaan beta-bloker tanpa nitrat mengalami episode syncope pada posisi berdiri.

Keamanan dan toleransi apomorfin sublingual (2-6 mg) telah diperiksa dalam beberapa lintas studi analisis, Insiden efek samping yang dilaporkan bervariasi secara luas. Dalam studi cross over yang melaporkan insiden tertinggi, efek samping yang paling umum ialah nausea, sakit kepala dan pusing yang terjadi pada frekuensi $6,8 \%, 6,7 \%$ dan 4,4\%, dimana masingmasing diberikan apomorfin dosis 2 dan 3 mg. Selain itu, yang putus obat karena menilai berhubungan dengan efek samping (drug-related adverse events) yaitu 2,3\%. Dengan dosis 2 atau $3 \mathrm{mg}$, akibat nausea turun dari 2,75\% dengan dosis pertama sampai $0,5 \%$ dengan dosis kedelapan yang menyatakan peningkatan toleransi terhadap nausea pada penggunaan secara terus menerus. Efek samping lain penggunaan apomorfin sublingual dengan insiden $>1 \%$ yaitu menguap, mengantuk, faringitis, dan retinitis. Tidak terdapat drug-related report dengan kematian, infark miokard, gangguan serebrovaskular, ereksi yang tidak kuat atau priapismus sejauh ini yang telah dilaporkan dalam percobaan klinis. ${ }^{32-34-36}$

Efek samping apomorfin sublingual ialah hipotensi arteri yang mungkin diperantarai oleh aktivasi reseptor-reseptor dopamin-1 vaskuler. Dalam penelitian uji klinik, apomorfin sublingual pada dosis hingga $5 \mathrm{mg}$ dapat menurunkan tekanan darah ortostatik yang lebih besar pada pasien yang secara bersamaan menggunakan nitrat jangka panjang atau golongan tertentu dari antihipertensi. Selain itu, efek samping yang paling bermakna dalam studi klinis ialah syncope, tetapi pasien dapat pulih lebih cepat. Keadaan syncope biasanya terjadi dalam kurun waktu 30-60 menit dan lebih dari 90\% kasus didahului oleh gejala prodormal vasovagal yang khas, yaitu terdiri dari satu atau lebih keadaan seperti nausea ringan sampai berat, pusing, muntah, vasodilatasi, pucat, dehidrasi, dan berkeringat. $^{35,36}$

\section{KERJA APOMORFIN SUBLINGUAL PADA EREKSI PENIS}

Sistem dopaminergik memainkan peran sentral dalam perilaku seksual pria. Episode ereksi penis yang ditunjukkan pada tikus percobaan meningkat berdasarkan respon terhadap injeksi intraperitoneal dari apomorfin. Respon tersebut dihambat oleh haloperidol (antagonis dopamin sentral), 
tetapi tidak dipengaruhi oleh domperidon (antagonis dopamin perifer). Selain itu, pemberian akut metaklopramid yang merupakan antagonis $\mathrm{D}_{2}$ selektif dapat menghambat apomorfin dalam induksi ereksi penis, sedangkan pemberian lisurid yang merupakan agonis $\mathrm{D}_{2}$ ke dalam PVN dapat meningkatkan tekanan intrakavernosa serta peningkatan serupa yang diinduksi oleh injeksi subkutan apomorfin yang telah dihambat oleh mikro-injeksi antagonis reseptor $\mathrm{D}_{1}$ atau $\mathrm{D}_{2}$. Data tersebut mendukung mekanisme yang diperantarai oleh reseptor $D_{2}$ dalam mencapai ereksi yang telah ditunjukkan pada tikus. ${ }^{33-36}$

Sebuah studi yang menggunakan MRI fungsional menunjukkan bahwa pemberian apomorfin sublingual disertai stimulasi seksual secara audio-visual menyebabkan secara nyata aktivitas yang lebih besar pada hipotalamus daripada dengan plasebo. Tempat kerja apomorfin ialah pada PVN yang kaya akan reseptor dopamin. Lesi elektrolisis pada PVN akan mencegah apomorfin dalam menginduksi respon erektogenik, dan mikroinjeksi beberapa nanogram yang mengandung apomorfin ke dalam PVN akan menginduksi ereksi penis. Efek ini diperantarai oleh neuron-neuron yang melepaskan oksitosin sebagai respon terhadap apomorfin. Neuromediator lainnya seperti glutamat, NO, dan oksitosin juga mampu mengaktivasi neuron-neuron dalam menginduksi ereksi penis. ${ }^{37-39}$

Dengan demikian, terdapat kemungkinan bahwa apomorfin meniru aktivasi neuron-neuron PVN melalui jalur hipotalamus-dopaminergik. Stimulasi dari reseptor $\mathrm{D}_{2}$ di PVN oleh apomorfin ini akan merangsang neuron-neuron oksitosinergik yang mengirim akson ke medula spinalis. Pada tikus, apomorfin juga langsung mengaktifkan sacral pro-erectile nucleus. Setelah stimulasi PVN, serat parasimpatis yang berperan dalam ereksi penis juga teraktivasi dan kemudian terjadi relaksasi otot polos penis, corporal engorgment (korpus kavernosum terisi darah), dan ereksi. Apomorfin sublingual merupakan agonis reseptor dopamin yang memulai dan meningkatkan respon ter- hadap ereksi penis melalui pusat kerja yang khas. Apomorfin sublingual mengandung campuran agonis reseptor dopamin D1 dan D2 dengan potensial aksi yang lebih pada aktivitas D2. Daya erektogennya berdasarkan efek terhadap hipotalamus (terutama PVN) yang kaya dengan reseptor dopamin. Aktivasi PVN akan memicu pro-erectile cascade yang diatur oleh neuron oksitonergik yang pada gilirannya akan merangsang pusat-pusat sakral medula spinalis (segmen S2-S4) untuk melepaskan NO dari transmisi saraf non-adrenergik non-kolinergik. Afinitas lokal dari NO yang berikatan dengan guanilil siklase akan mengonversi guanyl triphosphate menjadi cGMP sehingga menimbulkan relaksasi otot polos korpus kavernosum dan perubahan hemodinamik untuk mencapai ereksi. $^{39,40}$

\section{PENELITIAN UJI KLINIK}

Sampai saat ini, terdapat lebih dari 4000 pasien yang berpartisipasi dalam penelitian uji klinik apomorfin sublingual. Pasien yang direkrut dalam penelitian uji klinik ialah laki-laki dewasa dalam hubungan yang stabil dengan pasangan untuk sekurang-kurangnya enam bulan dan dengan riwayat minimal tiga bulan dalam ketidakmampuan untuk mencapai dan mempertahankan ereksi yang cukup untuk melakukan hubungan seksual pada lebih dari $50 \%$ percobaan tersebut. Yang terdaftar dalam program penelitian uji klinik juga termasuk pasien diabetes mellitus yang terkontrol, benign prostatic hyperplasia (BPH), penyakit arteri koroner (angina coronary artery bypass surgery, angioplasty dan myocardial infarction). Pasien dengan penyakit yang berhubungan dengan neurologi, abnormalitas endokrin, penyakit genitourinaria, gangguan psikiatri, HIV atau AIDS, kanker dengan remisi kurang dari lima tahun, dan riwayat penyalah-gunaan obat atau alkohol tidak dilibatkan dalam penelitian uji klinik. Pasien dengan hipersentivitas terhadap apomorfin dan seiring dengan penggunaan metaklopramid atau cisaprid (obat-obatan 
yang dapat menghambat efek pusat dari apomorfin sublingual) juga dikecualikan. Pengenalan atau perubahan dalam dosis anksiolitik, diuretik thiazid, x-metil dopa, klonidin, reserpin, dan guanitidin juga tidak diperbolehkan dalam protokol penelitian karena berpotensi memengaruhi fungsi seksual. $^{41}$

Studi double blind dan placebocontrolled yang mengevaluasi khasiat apomorfin sublingual dosis 2 mg selama 10-12 minggu pada 252 pasien dengan disfungsi ereksi, menunjukkan bahwa lebih dari $10 \%$ pasien-pasien dalam kelompok yang menerima apomorfin sublingual mencapai ereksi yang cukup kuat dalam melakukan hubungan seksual dibandingkan pasien-pasien yang menerima plasebo. Nilai intercourse rate (proporsi keberhasilan dalam melakukan hubungan seksual pada setiap percobaan) juga lebih tinggi pada apomorfin sublingual daripada placebo; oleh karena itu apomorfin sublingual $2 \mathrm{mg}$ dikonfirmasi efektif secara klinis pada pasien dengan disfungsi ereksi. ${ }^{41}$

Investigasi dilakukan pada studi double blind dan randomized-cross over terhadap khasiat apomorfin sublingual 3 mg dan hasilnya lebih bermakna dan efektif daripada plasebo untuk menghasilkan ereksi yang cukup dalam melakukan hubungan (46,9\% : 32,3\%), dengan nilai intercourse rate yang juga lebih tinggi dari placebo $(48,0 \%: 32,3 \%)$ seperti yang dilaporkan oleh pasien. $^{37-39,41}$

Waktu untuk mencapai ereksi atau pemulihan kemampuan seksual oleh apomorfin sublingual sangat cepat. Berdasarkan analisis dari 1918 respon ereksi terhadap apomorfin sublingual, nilai tengah untuk mencapai ereksi pada studi double blind dan placebo-controlled ialah 18,9 dan 18,8 menit untuk masing-masing apomorfin sublingual 2 dan 3mg. Pada sekitar 28\% pasien, ereksi tercapai dalam waktu 10 menit pada pemakaian apormofin sublingual. ${ }^{37,38,41}$

Dalam studi analisis terhadap pengaruh apomorfin sublingual pada fungsi ereksi dan kondisi komordibitas yang umumnya pada populasi lanjut usia, digunakan apomorfin sublingual 2 dan 3 mg dikombinasikan untuk evaluasi data penelitian di atas. Hasil yang diperoleh menunjukkan bahwa apomorfin sublingual secara bermakna lebih efektif daripada plasebo dalam menghasilkan ereksi pada pasien-pasien disfungsi ereksi ringan, sedang, dan berat. Derajat disfungsi ereksi berdasarkan International index of erectile function (IIEF) untuk yang ringan ( $P$ $<0,001)$, sedang $(P<0,001)$, dan berat $(P=$ $0,001)$. Demikian juga apomorfin sublingual lebih efektif pada pasien dengan penyakit jantung koroner, $\mathrm{BPH}$, hipertensi, dan diabetes melitus. ${ }^{37,38,41}$

Data dari pasien yang mendaftarkan diri dari studi penggunaan apomorfin sublingual jangka panjang menunjukkan bahwa yang menerima apomorfin sublingual 2 atau 3mg dan yang tetap bertahan dalam studi ini selama enam bulan atau lebih, 92\% menghasilkan ereksi yang cukup untuk melakukan hubungan setelah satu bulan menjalani pengobatan dan hasil tersebut sesuai dengan nilai sekitar 90\% setelah enam bulan menjalani pengobatan. Nilai-nilai yang sesuai pada pasien setelah menjalani pengobatan 12 dan 18 bulan ialah 98\% dan 88\%. Tidak ada bukti efek toleransi yang ditunjukkan apomorfin sublingual dalam penggunaan jangka panjang. $^{41}$

\section{SIMPULAN}

Apomorfin ialah suatu molekul mirip dopamin yang bekerja pada reseptor dopamin pada PVN di sistem saraf pusat untuk meningkatkan rangsangan erektil saat stimulasi seksual (imajinasi erotik, audio-visual, dan perabaan) terjadi. Apomorfin sublingual terbukti efektif untuk mengatasi disfungsi ereksi, terutama yang ringan dan sedang. Obat ini dapat digunakan oleh laki-laki berbagai usia (antara 45-66 tahun) dengan disfungsi ereksi, termasuk yang disertai komorbiditas umum untuk lanjut usia seperti penyakit arteri koroner, $\mathrm{BPH}$, hipertensi, dan diabetes mellitus. Pemakaian apomorfin sublingual secara berulang (empat kali 
pemakaian) dan pemkaian jangka panjang memberikan hasil yang lebih baik.

\section{DAFTAR PUSTAKA}

1. Rosen RC, Leiblum SR. Erectile disorder: Historical trends and clinical perspectives. In: Rosen RC, Leiblum SR, editors. Erectile Disorder: Assesment and Treatment. New York: Guildford Press, 1992:3-26.

2. Tendean OS. Reproduksi Seksual. Manado: Bagian Biologi FK UNSRAT, 2006.

3. Syamsir M. Disfungsi ereksi untuk lanjut usia: suatu tinjauan anatomi fungsional. Jurnal Kedokteran Yarsi. 2000;(1):115-21.

4. Lue TF. Erectile dysfunction. Drug therapy. Ed: Wood A. The New England Journal of Medicine. 2000;342(24):1802-10.

5. Leeson CR, Leeson TS, Paparo AA. Sistem reproduksi pria. Dalam: Tambayong J, editor. Buku Ajar Histologi (Edisi Kelima). Jakarta: Penerbit Buku Kedokteran EGC, 1989; p.533-6.

6. Karundeng R. Genitalia pria. Penuntun teori dan praktikum histologi. Bagian Anatomi Histologi. Manado: FK UNSRAT, 1999:8.

7. Teldford Ir, Bridgman CF. Male reproductive system. Introduction of functional histology (Second Edition). Harper Collins College Publishers, 1995; p.432.

8. Amenta PS, Elias H, Pauly JE. Reproductive system. Histology and human microanatomy. Italia: Piccin, 1991; p.563-9.

9. Anderson KE, Wagner G. Physiology of penile erection. Physiol. Rev. 1995; 75:191.

10. Ganiswara SG, Setiabudi R, Suyatna FB, Purwatyastuti. Farmakologi dan terapi (Edisi Keempat). Jakarta: Bagian farmakologi FKUI, 1995; p.113, 29-34.

11. Ganong WF, editor. Buku ajar fisiologi kedokteran (Edisi Kedelapanbelas). Alih bahasa: Widjajakusuma MD. Jakarta: Penerbit Buku Kedokteran EGC; 1998.

12. Traish AM, Carson MP, Kim N,
Goldstein I, Saenz de Tejada I. Characterization of muscarinic acetylcholine receptors in human penile corpus cavernosum: studies on whole tissue and cultured endothelium. J. Urol. 1990;(144):1036-40.

13. Fitzgerald RS, Shirahata $M$. Acetylecholine and carotid body excitation during hypoxia in the cat. J. Appl.Physiol. 1994;76:1566-74.

14. Robbins. Pathologic Basis of Disease (Sixth Edition). USA: WB Saunders Company, 1999; p.75.

15. Burnett A. Nitric oxide in the penis: physiology and pathology. J. Urol. 1997;157:320.

16. Siu shing chung. Medical Progeress: Erectile dysfunction in patient with type 2 diabetes. MediMedia pacific Ltd. 2002;29(9):24-5.

17. Artur J, James H, Dorothy S. Human Physiology: The mechanism of body function (Second Edition). McGrawHill Book Company, 1970; p.447-9.

18. Teldford Ir, Bridgman CF. Male reproductive system. Introduction of functional histology (Second Edition). Harper Collins College Publishers, 1995; p.432.

19. Mathiessen A, Wright CRA. Researches into the chemical constitution of the opium bases. Part I. On the action of hydrochloric acid on morphine. Proc Roy Soc Ser B. 1869;17:455-62.

20. Neumeyer JL, Lal S, Baldessarini RJ. Historical highlights of the chemistry, pharmacology, and early clinical uses of apomorphine. Apomorphine and other dopaminomimetics. In: Gessa GL, Corsini GU editors. Basic Pharmacology. New York: Raven Press, 1981; p.1-17.

21. The Department of Health. British Pharmacopoeia. London: The Stationery Of®ce, 2001: 141.

22. Vallone D, Picetti R, Borrelli E. Structure and function of dopamine receptors. Neurosci Biobehav Rev. 2000;24:125-32.

23. Product information. Uprima (Apomorphine SL). Abbott Laboratories, 2002.

24. Product information. Comtan (Entacapone). Novartis Pharmaceuticals, 2000. 
25. Product information. Tasmar (Tolcapone). Roche Laboratories Inc, 1998.

26. Fagan TC, Buttler S, Marbury T. Cardiovascular safety of sublingual apomorphine in patients on stable doses of oral antihypertensive agents and nitrates. Am J Cardiol. 2001;88:760-6.

27. Bohlen JG, Held JP, Sanderson MO, Patterson RP. Heart rate, ratepressure product, and oxygen uptake during four sexual activities. Arch Intern Med. 1984;144:1745-8.

28. Johnston BL, Fletcher GF. Dynamic electrocardiographic recording during sexual activity in recent postmyocardial infarction and revascularization patients. Am Heart J. 1979;98:736-41.

29. Ralph DJ, Sleep DJ, Perdok RJ, Padley RJ. Adverse events and patient tolerability of apomorphine SL 2 and $3 \mathrm{mg}$ : a cross-study analysis of phase II and III studies. Eur Urol. 2002;1:21-7.

30. Bukofzer S, Livesey $\mathbf{N}$. Safety and tolerability of apomorphine SL (Uprima). Int J Impot Res 2001; 13(Suppl 3):S40-4.

31. Padma-Nathan $H$, Auerbach S, Lewis $\mathbf{R}$, et al. Efficacy and safety of apomorphine SL versus placebo for male erectile dysfunction. J Urol. 1999;161(4S):214.

32. Dula E, Keating W, Siami PF. Efficacy and safety of fixed-dose and dose optimization regimens of sublingual apomorphine versus placebo in men with erectile dysfunction. The Apomorphine Study Group Urology. 2000;56:130-5.
33. Buvat J, Montorsi F. Safety and tolerability of apomorphine SL in patients with erectile dysfunction. BJU Int 2001;88(Suppl 3):S30- 5.

34. Heaton JPW. Neural and pharmacological determinants of erection. Int $\mathrm{J}$ Impot Res. 1996; 10(Suppl. 2):S35-9.

35. McKenna KE. Central control of penile erection. Int J Impot Res. 1998; 10(Suppl. 1):S25-34.

36. Giuliano FA, Rampin O, Benoit G, Jardin A. Neural control of penile erection. Urol Clin North Am. 1995; 22:747-66.

37. Marson L. Central nervous system control. In: Carson CC, Kirby R, Goldstein I, editors, Textbook of Erectile Dysfunction. Oxford: Isis Medical Media Ltd, 1999; p.73-88.

38. Wagner CK, Clemens LG. Projections of the paraventricular nucleus of the hypothalamus to the sexually dimorphic lumbosacral region of the spinal cord. Brain Res 1991;539:254-62.

39. Marson L, Platt KB, McKenna KE. Central nervous system innervation of the penis as revealed by the transneuronal transport of pseudorabies virus. Neuroscience. 1993; 55:263-80.

40. Chen KK, Chan SH, Chang LS, Chan JY. Participation of paraventricular nucleus of hypothalamus in central regulation of penile erection in the rat. J Urol. 1997;158:238-44.

41. Argiolas A, Melis MR. Neuromodulation of penile erection: an overview of the role of neurotransmitters and neuropeptides. Prog Neurobiol. 1995; 47:235-55. 